\title{
Effect of Accessibility on Commercial Property Rental Values Performance in Oja Oba Market, llorin Metropolis
}

\section{Rayyan Yusuf ${ }^{1}$, Ibrahim Hussaini Muhammad ${ }^{2}$, AbdulAkeem Olasunkanmi Otunola ${ }^{3}$, Sakariyau Jamiu Kayode ${ }^{4}$}

${ }^{1}$ Federal University of Kashere

P. M. B. 0182 Gombe, Gombe State, Nigeria

${ }^{2}$ Abubakar Tafawa Balewa University

Tafawa Balewa Way, P. M. B. 0248, Bauchi, 740272, Nigeria

${ }^{3}$ The Federal Polytechnic Offa

Federal Polytechnic Offa, P. M. B 420, Offa Kwara State

${ }^{4}$ Estate Surveyors and Valuers

B10 Danziyal Plaza, Opposite NNPC Mega Station, Central Area, Abuja, Nigeria

DOI: $10.22178 /$ pos. $77-7$

JEL Classification: 018

Received 20.11.2021

Accepted 28.12.2021

Published online 31.12.2021

Corresponding Author:

Jamiu Kayode

jamiuem@gmail.com

(C) 2021 The Authors. This article is licensed under a Creative Commons Attribution 4.0 License @ (1)

\begin{abstract}
The value of a commercial property is mainly determined by its interaccessibility to other land uses; accessibility is a critical component in determining the costs and rewards of any investment. The study is being conducted to investigate the impact of accessibility on the rental values of retail premises. The purpose of this study was to determine the extent to which accessibility affects the rental value of retail premises. The following goals were established: to assess the rent in various locations inside the market from the primary major route. The stratified random sample approach was employed to acquire the data to evaluate if there is a variance in rent and the link between rental value and distance. Data were examined using descriptive statistics and linear regression using SPSS. The data indicated that rent varies within the market as distance increases. It was found that as distance increases to the market, the rental prices of store premises fall, and there is a strong positive linear relationship between distance and rental value. The paper also advised that the government establish market parking space. The government should also give private shop property investors appropriate loans at cheap interest rates to boost investment in this sector.
\end{abstract}

Keywords: commercial properties; accessibility; rental value; llorin; Nigeria.

\section{INTRODUCTION}

Commercial assets, especially stores, are located at the most advantageous urban centres. These locations provide the chance to maximize returns. It has been noticed that homes closer to a central market road attract a higher rent [12]. The higher the property's value, the greater the demand for those with the highest degree of accessibility. The more viable it is to redevelop these sites since their appropriate convenience will allow for cost-effective and convenient transit of people, commodities, and services. It's also worth noting that the overall availability of land suited for a particular purpose is restricted; hence, the supply of potential metropolitan area sites is a fraction of the current transport system [5]. As a result, store layout must be determined by accessibility, and they must be located in such a way that they may optimize profit. The inter-accessibility of commercial properties to other land uses and clients determines their value. The properties with the highest rental values are placed on the most assessable roads, while those with the lowest rental values are located on the least assessable streets [16]. The location of a particular residential property has a significant impact on its value, determined by the demand for such property. Property in a good area commands a high rental value; property on the outskirts of a city controls a high rental value [17]. 
All else being equal, the closer these commercial properties are near these producing resources, the greater their rental value. The discrepancies in retail property rental values in the market have caused congestion in some market areas. The purpose of this study is to determine the extent to which accessibility influences commercial property rental values in Ilorin.

\section{LITERATURE REVIEW}

Commercial property often refers to buildings that house companies, although it may also apply to profit-generating land and more extensive residential rental properties. Classifying property as commercial affects the building's financing, tax treatment, and legislation that applies to it, offices and warehouses/industry, and retail malls [15]. Commercial property investments account for a significant share of all real estate investments globally. The value of commercial property in the United Kingdom is estimated to be $£ 762$ billion [4].

Author [4] said that real estate makes up a significant part of the cost base of the service and industrial sectors, accounting for about $44 \%$ of non-financial assets held by UK businesses. The nature and quality of commercial real estate also have a significant impact on the technical and organizational flexibility of the work environment, which has a substantial impact on efficiency in many service sectors. According to the study [15] noted that Real estate is a primary source of collateral security for loans. He also stated that real estate is responsible for three-quarters of UK bank financing. Authors [6] suggested that real estate makes up a significant portion of longterm institutional investors' investment portfolios in the United Kingdom. Most institutional investors in Finland invest primarily in office and retail assets [1]. The actual return on assets on office investment properties was associated with lower risk in London and highest in Moscow, according to a study undertaken by Jones Lang LaSalle and the Institute for Real Estate Research on premier office yields in chosen locations throughout the world. Like its real estate market, Nigeria's economy is in its early stages. Due to the lack of a trustworthy and standard real estate market database, the Nigerian commercial real estate market, in particular, has stayed relatively under-researched during the last five decades [14]. During this period, most property market research in Nigeria has been focused on the resi- dential property market, with a bit of comparative investigation of the region's commercial real estate market.

On average, commercial property returns in $\mathrm{Ni}$ geria are equivalent to that available elsewhere globally. Property investment transactions are often linked with poor yields across the world. These low returns have been discovered to suggest a rental increase [11]. This anticipation for rental growth validates one of the essential qualities of commercial property investments: income (rental) and capital appreciation [2]. Rental growth has been a significant expectation of property investors since the 1960, when the reverse-yield gap first appeared due to the introduction of rising prices into global property markets [4].

The market worth of a property while it is rented is referred to as rental value. The term "rent" has a variety of connotations. Author [7] claims that rent is defined as a monthly payment paid to a landlord and a fee for using the premises. In most circumstances, the rental values of identical commercial properties in one residential district within the same metropolis vary considerably from the rental prices of similar residential properties in another residential area within the same city.

Similarly, the rental value of identical residences in the same residential area varies for various causes that go unnoticed. The institute also pointed out that the relationships that generate value are complicated and that values shift as the elements that drive value shift. Utility, scarcity, desire, and adequate purchasing power are four interconnected economic elements that produce value.

Supply variables include utility and scarcity, whereas demand elements have the desire and adequate purchasing capacity. The capacity of a commodity to fulfil a human demand, need, or desire is referred to as utility. The current undersupply of an item to its request is known as scarcity. A purchaser's desire for a product to meet human wants is known as desire. In the case of adequate purchasing power, it is the ability of a person or group to participate in a market, i.e. to acquire products and services [10].

Several variables influence the decision to relocate, including accessibility, physical aspects of neighbourhood services and amenities, social environment, individual site, and home attributes 
[13]. They also claimed in the study that, in addition to all of the previously listed factors, location is one of the most important predictors of the property price. A property's or neighbourhood's location is a time-distance relationship or connectivity between it and all other probable origins and destinations of individuals going to or arriving from it. According to [6] a long-distance location with more appealing features and facilities will fetch higher value than a shorter distance site with fewer attractive features and amenities.

According to [3] the commercial property market is inextricably tied to the greater society since commercial buildings are subject to various macroeconomic, economic, political, social, and cultural forces. Author [3] observed that forces of demand and supply play a part in defining the future of the commercial real estate market. The main property businesses ' periodical real estate market synopses include many essential data, such as demand, supply, vacancy rates, absorption volume, planned projects, and macroeconomic variables, and legal and tax issues. Real estate markets, particularly the commercial property market, can benefit from these overviews.

These variables are essential for Nigerian developers and multinational corporations, construction companies, and developers entering the $\mathrm{Ni}$ gerian property market. The demand for commercial property in the Nigerian property market is increasing daily, particularly when the property is placed in a proper and strategic location. Furthermore, commercial property with advanced infrastructure and facilities will attract investors, increasing demand for commercial real estate. When such trends are based on rental values, the observation will be limited to any noticeable changes in rent trends. Real estate markets, particularly the commercial property market, can benefit from these overviews [18].

Because of the variability of real estate, rents and sales passing on properties are sure to be altered. These traits vary from innate to extrinsic [19]. Proximity to high-rise office buildings is one [9]. It is an undeniable truth that the provision of the following, as mentioned above, is the primary ingredient that will present the commercial property as physically feasible and economically viable [8].

\section{METHODOLOGY}

In this study, quantitative research approaches were used. A questionnaire was sent to the respondents to fill out and return. Owners of store premises, with 885 shops on the market, are the population under study in this research endeavour. Ninety-five people were chosen as the sample size for this study to represent the population. The study area's shop properties are at the core of the investigation, however, due to a large number of shop properties and the fact that they are located in different blocks within the market. The stratified random sampling approach was used to collect data for this study. The stratified random sampling entails separating the population into homogeneous subsets called strata and then sampling with systematic or straightforward methods. Zone A, B, and C are the three zones where the shops are located. This is done to guarantee that the sample is representative of the whole population or to ensure that the model is representative of the entire population. Following the comprehensive data collection, descriptive, mean ranking, and multiple regression were utilized to evaluate the data collected in the field using SPSS Version 22.

\section{RESULTS AND DISCUSSIONS}

The average means and means of the rental value of stores in Zones A, B, and C are shown in Tables 1-6.

Table 1 - Dissemination of Questionnaire

\begin{tabular}{|l|c|c|}
\hline \multicolumn{1}{|c|}{ Questionnaire } & Number & $\%$ \\
\hline $\begin{array}{l}\text { Total number of questionnaires } \\
\text { administered }\end{array}$ & 95 & 100 \\
\hline $\begin{array}{l}\text { Total number of questionnaires } \\
\text { retrieved }\end{array}$ & 76 & 80 \\
\hline
\end{tabular}

Notes: Author's field Survey, 2021

Table 2 - Distances of Shops from the Major Roads

\begin{tabular}{|c|c|c|c|}
\hline Zones & Distance in Metre & Single Shops & Total \\
\hline $\mathrm{A}$ & $0-60$ & 20 & 20 \\
\hline $\mathrm{B}$ & $61-120$ & 40 & 40 \\
\hline $\mathrm{C}$ & $121-180$ & 16 & 16 \\
\hline & & & 76 \\
\hline
\end{tabular}

Notes: Author's field Survey, 2021 
Table 3 - Rental Values of Single Shops in Zone A

\begin{tabular}{|l|l|l|l|l|l|l|l|l|}
\hline Shops & A & B & C & D & E & F & G & H \\
\hline $\begin{array}{l}\text { Rental } \\
\text { values }\end{array}$ & 80 & 80 & 80 & 85 & 90 & 90 & 85 & 90 \\
\hline
\end{tabular}

Notes: Author's field Survey, 2021

Table 4 - Rental Values of Single Shops in Zone B

\begin{tabular}{|l|l|l|l|l|l|l|l|l|}
\hline Shops & A & B & C & D & E & F & G & H \\
\hline $\begin{array}{l}\text { Rental } \\
\text { values }\end{array}$ & 70 & 70 & 75 & 70 & 70 & 70 & 75 & 65 \\
\hline
\end{tabular}

Notes: Author's work, 2021
Table 5 - Rental Values of Single Shops in Zone C

\begin{tabular}{|l|l|l|l|l|l|l|l|l|}
\hline Shops & A & B & C & D & E & F & G & H \\
\hline $\begin{array}{l}\text { Rental } \\
\text { values }\end{array}$ & 60 & 60 & 60 & 60 & 65 & 55 & 60 & 55 \\
\hline
\end{tabular}

Notes: Author's work, 2021

Table 6 - Average and Mean Rental Value in Single Shops in Zone A B and C

\begin{tabular}{|c|c|c|c|c|c|c|c|c|c|}
\hline \multirow[t]{2}{*}{ Zone } & \multirow{2}{*}{$\begin{array}{l}\text { Name of } \\
\text { Shop }\end{array}$} & \multirow{2}{*}{\begin{tabular}{|l} 
No \\
10
\end{tabular}} & \multirow{2}{*}{$\begin{array}{c}\begin{array}{c}\text { Average } \\
\text { Range }\end{array} \\
\text { (N) }\end{array}$} & \multirow{2}{*}{$\begin{array}{l}\text { Minimum } \\
\text { Range } \\
\text { (N) }\end{array}$} & \multirow{2}{*}{$\begin{array}{c}\text { Maximum } \\
\text { Range } \\
(\mathrm{N})\end{array}$} & \multicolumn{2}{|c|}{ Mean } & \multirow[t]{2}{*}{$\begin{array}{l}\text { Standard De- } \\
\text { viation }\end{array}$} & \multirow[t]{2}{*}{ Variance } \\
\hline & & & & & & Stat & Std. & & \\
\hline A & & 10 & 15,000 & 135,000 & 150,000 & $8.40 \mathrm{E} 4$ & & & \\
\hline B & & 8 & & & & & & & \\
\hline $\mathrm{C}$ & Single & 9 & 15,000 & 50,000 & 65,000 & $5.83 \mathrm{E} 4$ & 1443.376 & 4330.127 & $1.875 \mathrm{E} 7$ \\
\hline
\end{tabular}

Notes: Author's work, 2021

As depicted, the difference in rental value is attributable to the distance between the retail premises and the major road. According to the data, the relative length of the homes from the significant road affected the rent paid for the property. As a result, the rental value on a highly accessible route will be more excellent.
Linear regression was used to demonstrate the association between the two variables better. The coefficient of determination $\left(\mathrm{R}^{2}\right)$ was 0.272 , and the F-Value was 0.373 , indicating that the two variables had a strong linear positive connection (Table 7-8).

Table 7 - Regression Results

\begin{tabular}{|c|c|c|c|c|c|c|}
\hline Mode & $\mathrm{R}$ & $\mathrm{R}^{2}$ & Adjusted $\mathrm{R}^{2}$ & Std Error & $\mathrm{R}^{2}$ Change & F Change \\
\hline 1 & $0.521 \mathrm{a})$ & 0.572 & -0.457 & 1.207 & 0.272 & 0.373 \\
\hline
\end{tabular}

Notes: Author's work, 2021

Table 8 - Estimated ANOVA Result for Single Shops (A)

\begin{tabular}{|c|c|c|c|c|}
\hline Model & Sum of Squares & Mean Square & F & SIG \\
\hline Regression & 0.543 & 0.543 & 0.373 & $0.652 \mathrm{a})$ \\
\hline Residual & 1.547 & & & \\
\hline Total & 2.00 & & & \\
\hline
\end{tabular}

Notes: Author's work, 2021

Table 8 - Estimated ANOVA Result for Single Shops (B)

\begin{tabular}{|c|c|c|c|c|c|}
\hline \multirow{2}{*}{ Variable } & \multicolumn{2}{|c|}{ Unstandard Coefficient } & Standard Coefficient & t-value & SIG \\
\cline { 2 - 6 } & Beta & Std Squares & & & \\
\hline (constant) & 6.122 & 4.763 & 0.521 & 1.285 & 0.421 \\
\hline Rental Values & $4.055 \mathrm{E} 5$ & 0.000 & & .611 & .651 \\
\hline
\end{tabular}

Notes: Author's work, 2021. Predictors: Constant, Rental Values. Dependent Variable: Distance.

a) Dependent Variable. $R^{2}-0.272$. Adjusted $R^{2}=-0.457$. F-Value $=0.373$. Significant at $0.451 \%$ 


\section{CONCLUSIONS}

After establishing the influence of accessibility on commercial property rental prices, it is essential to mention that one of the primary issues confronting outlying districts in Ilorin is the poor quality of roads, which has continued to obstruct accessibility. Even if the available space is tiny, businesses prefer to have a place in an easily accessible area. This is because certain stores fetch cheaper rentals due to their inaccessibility. The rental value of comparable properties in different zones within the research region varies. The quality of the environment influences their rental values. Because the Land Use Charge is based on the value of the commercial property, improving the state of the roads would benefit not only the government, as it would tax highly valued properties at a higher rate. But also, the owners, who would pass the cost on to their tenants through higher rental payments.

Accessibility is a significant benefit that increases the leasing value of a store. As a result, it is critical that the government creates, rehabilitates, and effectively maintains roads in these areas to improve accessibility and overall usage. This is because a better road network makes it easier to move around and circulate and reach productive resources and sites inside a neighbourhood and the city. Not only should the government build parking spaces in the market, but it should also boost the property's aesthetic worth.

\section{REFERENCES}

1. Ammann, R. (2019). ESG Integration Among Large Nordic Institutional Asset Owners. Retrieved from http://kth.diva-portal.org/smash/get/diva2:1345874/FULLTEXT01.pdf

2. Baker, S. R. (2018). Debt and the Response to Household Income Shocks: Validation and Application of Linked Financial Account Data. Journal of Political Economy, 126(4), 1504-1557.

3. Cvetkovich, A., \& Kellner, D. (1996). Articulating the global and the local. Globalization and cultural studies. London: Routledge.

4. Hassanali, J. Y. (2019). Determinants of investment decisions on uptake of commercial properties: a case of Westlands area in Nairobi - Kenya (Doctoral dissertation). Retrieved from http://erepo.usiu.ac.ke/bitstream/handle/11732/4621/HASSANALI\%2c\%20JUZER\%20YUNU S\%20MBA\%202019.pdf?sequence=1\&isAllowed=y

5. Henderson, J. V. (2014). Economic theory and the cities. doi: 10.1016/c2009-0-21824-1

6. Hofman, A., \& Aalbers, M. B. (2019). A finance- and real estate-driven regime in the United Kingdom. Geoforum, 100, 89-100. doi: 10.1016/j.geoforum.2019.02.014

7. Hood, A. (2001). Continuous operation clauses and going dark. Real Property, Probate and Trust Journal, 36(2), 365-390.

8. Kashef, M. (2016). Urban livability across disciplinary and professional boundaries. Frontiers of Architectural Research, 5(2), 239-253. doi: 10.1016/j.foar.2016.03.003

9. Lim, Y.-W., \& Heng, C. Y. S. (2016). Dynamic internal light shelf for tropical daylighting in high-rise office buildings. Building and Environment, 106, 155-166. doi: 10.1016/j.buildenv.2016.06.030

10. Lysons, K., \& Farrington, B. (2010). Purchasing and supply chain management. London: Pearson Education India.

11. Malpezzi, S. (2014). Global perspectives on housing markets and policy. Retrieved from https://marroninstitute.nyu.edu/uploads/content/Global_Perspectives_on_Housing_Markets_a nd_Policy.pdf

12. Mashiri, L., Karam, A. (2019). Impact of Rail Transit Stations and Value Capture Planning for Transit in Johannesburg, South Africa. Retrieved from https://ideas.repec.org/p/afr/wpaper/2021025.html 
13. Mohit, M. A., Ibrahim, M., \& Rashid, Y. R. (2010). Assessment of residential satisfaction in newly designed public low-cost housing in Kuala Lumpur, Malaysia. Habitat International, 34(1), 1827. doi: 10.1016/j.habitatint.2009.04.002

14. Onwuanyi, N., \& Oyetunji, A. K. (2021). The relevance of inter-market research to knowledge accessibility in property markets: lessons for Nigeria from the UK. Property Management, 39(5), 702-725. doi: 10.1108/pm-01-2021-0001

15. Osazuwa, P. E., \& Ekenta, C. (2020). Challenges to Commercial Property Taxation in Obio/Akpor Local Government Area of Rivers State. Journal of Environmental Science, Computer Science and Engineering \& Technology 9 (1), 58-71.

16. Osazuwa, P. E., \& Ekenta, C. (2020). Challenges to Commercial Property Taxation in Obio/Akpor Local Government Area of Rivers State. Journal of Environmental Science, Computer Science And Engineering \& Technology, 9(1). doi: 10.24214/jecet.b.9.1.05871

17. Rossi, F., \& Chintagunta, P. K. (2016). Price Transparency and Retail Prices: Evidence from Fuel Price Signs in the Italian Highway System. Journal of Marketing Research, 53(3), 407-423. doi: 10.1509/jmr.14.0411

18. Sakariyau, J. K., Ajibade K, R., Muhammad, M. M., Hafsatu, J. B., Joab, S. K., \& Yusuf, G. L. (2020). An Analysis of Trends in Residential Property Value in Gwallameji, Bauchi, Bauchi State, Nigeria. International Journal of Management Science and Entrepreneurship, 11(7), 104-135.

19. Warren-Myers, G. (2012). The value of sustainability in real estate: a review from a valuation perspective. Journal of Property Investment \& Finance, 30(2), 115-144. doi: $10.1108 / 14635781211206887$

20. Xiao, Y., \& Webster, C. (2017). Urban morphology and housing market. Retrieved from https://link.springer.com/book/10.1007/978-981-10-2762-8\#toc 